\title{
Peningkatan Aktivitas Belajar Siswa pada Mata Pelajaran Ilmu Pengetahuan Alam melalui Metode Kelompok Sindikat (Syindicate Group) di Kelas V Sekolah Dasar Negeri 009 Teratak
}

\author{
Sunarti \\ Universitas Islam Negeri Sultan Syarif Kasim Riau, Indonesia \\ e-mail: sunartiunar4@gamil.com
}

\begin{abstract}
.
This research aims to improve student learning activities on subjects of natural knowledge trough method group syndicate (syndicate group). The willingness by the low activity of student learning in Natural Science subjects. Formulation of the problem in this research is how improved student learning activities with the aplication of the method of group syndicate (syndicate group) on subjects natural in class v State primary school 009 Teratak of Rumbio Jaya subdistrict of Kampar Regency. This research is a research action class that consists of four stages each cycle is the Planning Act, the implementation of the action, observation, and reflection. This research was conducted as many as two cycles, each cycle consisting of two times. The subject of this research is the teacher and students with a number of students as many as 14 people. Objects in research is the improvement of student learning activities. Data collection on this research by using the teachniques of observation and documentation. Technique of data analysis of this research is to use the technique of analysis of descriftive. The results showed students in learning activities before the Act is $41.07 \%$ with the category of failed. Then after applying the method group syndicate (syndicate group) in cycle I, the learning activities of students increased to $58.42 \%$ with the category of less. in cycle II, increasing student learning activities become $77.81 \%$. Can be concluded that, through the syndicate group method student learning activities can increase.
\end{abstract}

Keywords: Method Syndicate Group, Students Learning Activities

\begin{abstract}
ABSTRAK
Penelitian ini bertujuan untuk meningkatkan aktivitas belajar siswa pada mata pelajaran Ilmu Pengetahuan Alam melalui metode kelompok sindikat. Penelitian ini dilatarbelakangi oleh rendahnya aktivitas belajar siswa dalam mata pelajaran Ilmu Pengetahuan Alam. Rumusan masalah dalam penelitian ini adalah bagaimana meningkatkan aktivitas belajar siswa dengan penerapan metode kelompok sindikat pada mata pelajaran ilmu pengetahuan alam di kelas V Sekolah Dasar Negeri 009 Teratak Kecamatan Rumbio Jaya Kabupaten Kampar. Penelitian ini merupakan penelitian tindakan kelas yang terdiri dari empat tahap setiap siklus yaitu perencanaan, pelaksanaan tindakan, observasi, dan refleksi. Penelitian ini dilakukan sebanyak dua siklus, setiap siklus terdiri dari dua kali. Subjek penelitian ini adalah guru dan siswa dengan jumlah siswa sebanyak 14 orang. Objek dalam penelitian adalah peningkatan aktivitas belajar siswa. Pengumpulan data pada penelitian ini dengan menggunakan teknik observasi dan dokumentasi. Teknik analisis data penelitian ini adalah dengan menggunakan teknik analisis deskripsi. Hasil penelitian menunjukkan siswa dalam kegiatan pembelajaran sebelum penerapan metode adalah 41,07\% dengan kategori gagal. Setelah menerapkan metode kelompok sindikat pada siklus I, aktivitas belajar siswa meningkat menjadi 58,42\% dengan kategori kurang. Pada siklus II, meningkatkan aktivitas belajar siswa menjadi 77,81\%. Dapat disimpulkan bahwa, melalui metode kelompok sindikat kegiatan belajar siswa dapat meningkat.
\end{abstract}

Kata kunci: Metode Syndicate Group, Kegiatan Belajar Siswa 


\section{PENDAHULUAN}

Pendidikan merupakan aspek yang sangat penting bagi perkembangan pembangunan suatu bangsa, dengan mutu pendidikan yang baik maka akan menciptakan sumber daya manusia yang bermutu tinggi, dan dengan pendidikan akan menciptakan manusia-manusia menjadi dewasa dan tumbuh dengan nilai-nilai kemanusiaan. Pendidikan adalah suatu proses pembelajaran untuk menumbuhkembangkan potensi yang ada dalam diri manusia baik jasmani dan rohaninya dalam tingkatan afektif, kognitif dan psikomotor. Problematika pendidikan saat ini tidak hanya bisa dilihat dari suatu aspek saja, melainkan didalamnya terdapat berbagai insturmen yang memberi pengaruh terhadap mutu pendidikan tersebut.

Problematika ini seharusnya harus kita perbaiki demi lahirnya out come yang berkualitas, namun untuk memberikan pendidikan yang baik dan bermutu bagi masyarakat, dalam menciptakan pendidikan yang berkualitas tidak hanya membutuhkan sarana dan prasarana yang berkualitas saja, tetapi juga harus dibarengi dengan kualitas pendidik yang bagus saat melaksanakan tugasnya dalam mendidik, memiliki keterampilan dalam mengajar serta memiliki kompetensi sebagai pendidik.

Pendidikan adalah perbuatan manusiawi. Pendidikan lahir dari pergaulan antara orang dewasa dan orang yang belum dewasa dalam suatu kesatuan hidup. Tindakan mendidik yang dilakukan oleh orang dewasa dengan sadar dan sengaja didasari oleh nilainilai kemanusiaan.Tindakan tersebut menyebabkan orang yang belum dewasa menjadi dewasa dengan memiliki nilai-nilai kemanusiaan, dan hidup menurut nilai-nilai tersebut. Kedewasaan diri merupakan tujuan pendidikan yang hendak dicapai melalui perbuatan atau tindakan pendidikan (Hasbullah, 2011:5).

Tujuan pendidikan yang diharapkan adalah menciptakan out come pendidikan yang berkualitas sesuai dengan yang diharapkan oleh berbagai pihak. Tentunya pendidikan diharapkan mampu membawa perubahan kepada tarap kehidupan yang lebih baik, karena pendidikan akan memberikan perbubahan kepada kualiats sumber daya manusianya. Hal itu tidak terlepas pula dengan manajemen pendidikan itu sendiri. Manajemen pendidikan yang bagus dapat diciptakan dan dapat dilaksanakan oleh manajer pendidikan yang berkualitas. Manajer pendidikan salah satunya adalah guru. Tugas guru selain mengajar, juga menjadi seorang manajer pendidikan. Seorang guru harus merencanakan manajemen kelas yang baik.

Dalam proses pembelajaran terdapat kegiatan belajar-mengajar, dan transaksi ilmu yang diberikan oleh pendidik ke peserta didik. Belajar adalah tindakan dan perilaku siswa yang kompleks. Sebagai tindakan, maka belajar hanya dialami oleh siswa sendiri. Siswa adalah penentu terjadinya atau tidak terjadinya proses belajar. Proses belajar terjadi berkat siswa memperoleh sesuatu yang ada di lingkungan sekitar. Lingkungan yang dipelajari oleh siswa berupa keadaan alam, benda-benda, hewan, tumbuh-tumbuhan, manusia, atau hal-hal yang dijadikan bahan belajar. Tindakan belajar tentang suatu hal tersebut tampak sebagai perilaku belajar yang tampak dari luar (Dimyanti dan Mudjiono, 2006:17). Sedangkan mengajar adalah tugas guru untuk menuangkan sejumlah bahan pelajaran ke dalam otak anak didik. Guru yang mengajar dan anak didik yang belajar (Syaiful Bahri Djamarah, 2011:107). Mengajar juga diartikan sebagai penanaman ilmu-ilmu yang dilakukan oleh guru terhadap peserta didik.

Proses belajar mengajar merupakan serangkaian perbuatan guru dan siswa, adanya interaksi dan timbal balik antara keduanya. Pembelajaran bukan hanya sekedar penyampaian materi saja melainkan seorang guru juga dituntut untuk menanamkan sikap dan nilai-nilai pada diri siswa yang sedang belajar. Oleh sebab itu guru memiliki banyak peran saat berada dalam kelas. Peran guru dalam pendidikan merupakan sesuatu hal yang 
sangat penting. Keberhasil suatu pembelajaranpun ditentukan oleh guru, oleh karena itu guru harus meiliki kompetensi dalam mengolah kelas sehingga proses pembelajaran yang efektif dapat terlaksana. Guru tidak hanya menjadi fasilitator dalam kelas, lebih dari itu guru harus membangun kedekataan emosional dengan siswa, karena apabila kedekatan itu terbangun akan membawa dampak kepada semangat siswa dalam mengikuti proses pembelajaran. Sering kita jumpai, dalam proses pembelajaran guru dan siswa sepeprti memiliki batasan, tidak ada chemistry membuat proses pembelajaran terasa canggung dan kaku.

Seorang guru haruslah memiliki kompetensi-kompetsni dalam dirinya, adapun komptensi guru yang paling utama adalah kemampuan sorang guru melaksanakan kewajiban-kewajiban secara bertanggung jawab dan layak. Kompetensi ini berkaitan dengan profesional yaitu guru yang profesional adalah guru yang berkopeten, karena kompetensi profesional guru dapat diartikan sebagai kemampuan dan kewenangan guru dalam menjalankan profesi keguruannya dengan kemampuan baik. Dengan kata lain kompetensi adalah keterampilan dan kemampuan yang dimiliki oleh seorang guru. Guru adalah pelaku utama dalam pembelajaran, oleh karena itu guru diharapkan memiliki kompetensikompetsni yang bagus.

Dalam proses pembelajaran guru mempunyai tugas untuk mendorong, membimbing, dan memfasilitasi belajar untuki siswa demi mencapai tujuan. Guru mempunyai tanggung jawab dalam melihat serta mengarahkan perkembangan yang ada pada diri siswa, mengembangkan potensi-potensi yang dimiliki siswa. Namun terkadang, guru berubah peran dari seorang pendidik menjadi penceramah di dalam kelas, karena guru tidak berkopetensi dalam mendesain pembelajaran dengan menerapkan metode-metode dan tidak kreatif dalam membuat media.

Guru menempati kedudukan sentral, sebab peranannya sangat menentukan. Ia harus mampu menterjemahkan dan menjabarkan nilai-nilai yang terdapat dalam kurikulum, kemudian menstranformasikan nilai-nilai tersebut kepada siswa melalui proses pembelajaran di sekolah (Nana Sudjana, 2011:1). Sekolah dalam pendidikan formal dimulai dari tingkat Sekolah Dasar. Sekolah Dasar ditempuh dalam waktu 6 tahun. Lulusan Sekolah Dasar dapat melanjutkan pendidikan ke Sekolah Menengah Pertama (atau sederajat).

Pada pendidikan Sekolah Dasar seorang guru harus banyak menguasai disiplin ilmu, menguasai berbagai macam pengetahuan tentang tema-tema yang dipelajari dalam mata pelajaran tertentu, misalnya tentang sifat-sifat cahaya, berhitung, sosial budaya dan lain sebagainya. Masa usia sekolah dasar sebagai masa kanak-kanak akhir yang berlangsung dari usai enam tahun hingga kira-kira usia sebelas tahun atau dua belas tahun. Karakteristik utama siswa sekolah dasar iniadalah yang menyukai sesuatu yang menyenagkan. Tantangan seorang guru sekolah dasar yang paling besar adalah menjadikan suatu pembelajaran menjadi sesuatu yang menyenangkan baagi siswa, terutama pada usia sekolah dasar yang sangat mudah bosan dan jenuh. Guru dituntut untuk terampil dalam mengolah kelas, merancanng proses pembelajaran menjadi sesuatu yang menari terutama pada mata pelajaran yang sifatnya berfokus pada aspek kognitif siswa.

Salah satu mata pelajaran disekolah yang mempelajari tentang sifat-sifat cahaya adalah Ilmu Pengetahuan Alam. Ilmu Pengetahuan Alam adalah sebagai sekumpulan pengetahuan tentang objek dan fenomena alam yang diperoleh dari hasil pemikiran dan penyelidikan ilmuan yang dilakukan dengan keterampilan bereksperimen dengan menggunakan metode ilmiah (Susilawati, 2013:3). Mata pelejaran IPA seringkali mendapat penilaian buruk dari siswa, dengan alasan IPA adalah mata pelajaran yang sulit dipahami, memiliki istilah-istilah yang susah dipahami siswa. Namun argumen yang disampaikan oleh 
sisiwa bahwa mata pelajaran IPA yang dianggp susah bisa dipatahkan oleh guru dengan cara memilih metode atau strategi yang cocok dalam setiap materi.

Itulah pentingnya kompetensi dan keterampilan bagi seorang guru. Karena mengajar bukan hanya berceramah didepan kelas, tetapi bagaimana potensi-potensi siswa juga dapat terealisaikan dalam proses pembelajaran. Proses pembelajaran yang seperti ini merupakan pembelajaran yang berpusat kepada siswa (student centered). Dengan proses pembelajaran seperti ini diberikan kesempatan kepada siswa dalam mengembangkan potensinya, jadi siswa tidak hanya sekedar duduk dengar lalu materi yang disampaikan cepat dilupakan dan membosankan. Untuk menjadikan proses pembelajaran itu menjadi sesuatu yang menyenangkan itulah tugas utama guru dan pembelajaran yang menyenangkan sangat diperlukan oleh siswa, karena sesuatu yang dilakukan dengan perasaan senang pasti akan lama dalam ingatan.

Dalam mata pelajaran Ilmu Pengetahuan Alam seorang guru hendaknya memiliki kompetensi dalam menyampaikan materi. Pada hakikatnya mata pelajaran Ilmu Pengetahuan Alam bukan hanya kemampuan kognitif dan psikomotor siswa saja, tetapi juga menuntut siswa untuk berperan aktif dalam proses pembelajaran. Untuk mewujudkan proses pembelajaran Ilmu Pengetahuan Alam seperti yang diharapkan maka seorang guru harus membuat perencanaan pembelajaran yang matang dan telah dipersiapkan terlebih dahulu. Dalam pelaksanaannya guru harus memilih strategi dan metode yang tepat untuk menciptakan suasana belajar yang aktif sehingga tujuan pembelajaran Ilmu Pengetahuan Alam akan tercapai sesuai yang telah diharapkan. Pemilihan strategi dan metode yang tepat akan mempengaruhi terhadap proses pembelajaran yang sedang dilaksanakan, dan dari proses tersebut akan mempengaruhi tingkat keberhasilan pembelajaran.

Namun pada kenyataannya berdasarkan pengamatan yang peneliti lakukan pada siswa Kelas V Sekolah Dasar Negeri 009 Teratak Kecamatan Rumbio Jaya Kabupaten Kampar, aktivitas belajarnya dalam kategori rendah. Dari hasil observasi awal dan wawancara dengan guru kelas V pada mata pelajaran IPA di SD 009 Teratak kecamatan Rumbio Jaya Kabupaten Kampar, mengatakan bahwa dikelas $\mathrm{V}$ aktivitas siswanya sanggat lemah, jika diberikan kesempatan bertanya, dari 14 orang siswa hanya 7 orang siswa atau sebanyak 50\% yang bertanya, dari 14 orang siswa hanya 5 orang atau 35,7\% yang memberikan pendapat ketika guru mengajukan pertanyaan, jika diberikan tugas hanya 10 orang yang aktif mengerjakannya, sedangkan yang lainnya hanya menunggu jawaban teman. Hal ini disebabkan pada proses pembelajarannya masih berpusat kepada guru sehingga proses pembelajaran kurang menarik. Dan juga dalam memilih strategi dan metode guru tidak melihat karakteristik siswa dalam kelas dan karakteristik materi yang diajarkan menyebabkan strategi dan metode tersebut tidak terlaksana dengan baik dan menoton. Guru hanya berceramah dan memberikan penyajian materi mengakibatkan siswa kurang dilibatkan dalam mencari informasi dalam materi. Kemudian memberikan tugas hanya berdasarkan buku paket dan dampaknya terlihat pada aktivitas siswa yang kurang aktifBerdasarkan latar belakang diatas, maka peneliti melakukan penelitian untuk meningkatkan aktivitas siswa pada mata pelajaran IPA kelas V dengan metode kelompok sindikat (syndicate group) di SD 009 Teratak Kecamatan Rumbio Jaya Kabupaten Kampar.

\section{KAJIAN LITERATUR}

\section{Aktivitas Belajar}

Belajar sangat membutuhkan adanya aktivitas, karena tanpa adanya aktivitas proses pembelajaran tidak dapat terlaksana dengan baik. Aktivitas belajar meliputi dari berbagai bentuk tindakan fisik dan mental. aktivitas yang bersifat fisik bisa dilihat dari berbagai 
tindakan-tindakan yang dilakukan, sedangkan aktivitas yang bersifat mental ini bisa dilihat dari emosional siswa, ketertarikan pada saat mengikuti pembelajaran. Kedua aktivitas ini saling berkaitan sehingga terlaksananya aktivitas belajar yang efektif.

Siswa mempunyai potensi untuk aktif dalam pembelajaran. Pengajaran efektif adalah pengajaran yang menyediakan kesempatan belajar sendiri atau melakukan aktivitas sendiri kepada peserta didik. Peserta didik belajar sambil bekerja. Dengan bekerja mereka memperoleh pengetahuan, pemahaman, dan aspek-aspek tingkah laku lainnya, serta mengembangkan keterampilan yang bermakna untuk hidup masyarakat (Oemar Hamalik, 2006:171-172).Aktivitas merupakan prinsip atau asas yang sangat penting dalam berinteraksi pada pembelajaran, dengan kata lain tidak ada belajar apabila tidak ada aktivitas (Sardiman, 2001: 93). Berdasarkan pendapat tersebut, dapat dipahami bahwa aktivitas belajar merupakan kegiatan yang menuntut siswa untuk berperan aktif dalam proses pembelajaran, baik itu mengeluarkan pendapat, bertanya, memberi tanggapan, dan berperan aktif dibidang lainnya.

Adapun yang menjadi indikator aktivitas Menurut Paul D. Dierich dalam Oemar Hamalik (2006:172-173) adalah (1)Visual activities, seperti membaca, memperhatikan gambar, demonstrasi, percobaan pekerjaan orang lain dan sebagainya, (2) Oral Activities, seperti menyatakan, merumuskan, bertanya, memberi saran, mengeluarkan pendapat, interviu, diskusi dan sebagainya, (3) Listening activities, seperti mendengarkan uraian, percakapan diskusi, musik, pidato, ceramah dan sebagainya, (4) Writing activities, seperti menulis certita, karangan, laporan, angket, menyalin dan sebagainya, (6) Drawing activities, seperti menggambarkan, membuat grafik, peta, patroon dan sebagainya, (7) Motor activities, seperti melakukan percobaan, membuat konstruksi, model reparasi, bermain, berkebun, memelihara binatang dan sebagainya, (8) Mental activities, seperti menanggap, engingat, memecahkan soal, menganalisis, mengambil keputusan dan sebagainya, (9) Emotional activities, seperti menaruh minat, gembira, berani, tenang, gugup, kagum dan sebagainya.

Sedangkan menurut Syaiful Bahri Djamarah (2011: 38-45) dalam bukunya Psikologi Belajar, jenis-jenis aktivitas adalah: (1) Mendengarkan suatu aktivitas belajar. Setiap orang yang belajar disekolah pasti ada aktivitas mendengarkan. Ketika seorang guru menggunakan metode ceramah, maka setiap siswa diharuskan mendengarkan apa yang guru sampaikan. Menjadi pendengar yang baik dituntut dari mereka, (2) Memandang; mengarahkan penglihatan ke suatu objek. Aktivitas memandang berhubungan erat dengan mata. Karena dalam memandang itu matalah yang memegang peranan penting. Aktivitas memandang termasuk dalam kategori aktivitas belajar. di kelas, seorang pelajar memandang papan tulis yang berisikan tulisan yang baru saja guru tulis. Tulisan yang pelajar pandang itu menimbulkan kesan dan selanjtnya tersimpan dalam otak. $\quad$ (3) Meraba, Membau, dan Mencicipi/Mengecap. Aktivitas meraba, membau, dan mengecap adalah indra manusia yang dapat dijadikan sebagai alat untuk kepentingan belajar. Artinya aktivitas meraba, membau, dan mengecap dapat memberikan kesempatan bagi seseorang untuk belajar. Tentu saja aktivitasnya harus disadari oleh suatu tujuan. Dengan demikian aktivitas-aktivitas meraba, aktivitas membau, ataupun aktivitas mengecap dapat dikatakan belajar, apabila semua aktivitas itu didorong oleh kebutuhan, motivasi untuk mencapai tujuan dengan menggunakan situasi tertentu untuk memperoleh perubahan tingkah laku, (4) Menulis atau mencatat kegiatan aktivitas belajar. Dalam pendidikan tradisional kegiatan mencatat merupakan kegiatan yang sering dilakukan. Dalam mencatat tidak sekedar mencatat tetapi yang dapat menunjang pencapaian tujuan belajar, (5) Membaca, membaca disini tidak mesti membaca buku belaka, tetapi juga majalah, koran, tabloid, jurnal-jurnal hasil penelitian , catatan hasil belajar atau kuliah, dan hal-hal lainna yang berhubungan dengan kebutuhan studi, (6) Membuat Ikhtisar atau ringkasan atau menggarisbawahi. Banyak orang yang 
merasa terbantu dalam belajarnya karena menggunakan ikhtisar-ikhtisar nmateri yang dibuatnya. Ikhtisatr atau ringkasan ini memang dapat membantu dalam hal mengingat, mencari kembali materi dalam buku untuk masa-masa yang akan dating, (7) Mengamati tabel-tabel, diagram-diagram dan bagan-bagan. Dalam buku ataupun dilngkungan lain sering dijumpai tabel-tabel, diagram, ata bagan-bagan. Materi non verbal semacam ini sangat berguna bagi seseorang dalam mempelajari materi yang relevan. Demikian pula gambar-gambar, peta-peta, dan lain-lain dapat menjadi bahan ilustratif yang membantu pemahaman seseorang tentang sesuatu hal, (8) Menyusun paper atau kertas kerja. Dalam menyusun paper tidak bisa sembarang, tetapi harus metodologis dan sistematis.Ketika seseorang ingin membuat paper bukan harus mempersoalkan judulnya, tapi yang harus dipermasalahkan adalah misalnya, untuk menguasai masalah harus digali dari sumbernya yaitu buku. Hal ini dikategorikan sebagai aktivitas, (9) Mengingat; mengingat adalah salah satu aktivitas belajar. Tidak ada seorangpun yang tidak pernah mengingat dalam belajar. Perbuatan mengingat jelas sekali terlihat ketika seseorang sedang menghafal bahan pelajaran, berupa dalil, kaidah, pengertian, dan sebagainya. (10) Berpikir; Berpikir adalah termasuk aktivitas belajar. Dengan berpikir orang memperoleh penemuan baru. Setidaktidaknya orang menjadi tahu tentang hubungan antara sesuatu, (11) Latihan atau praktek. Learning by doing adalah konsep belajar yang menghendaki adanya penyatuan usaha mendapatkan kesan-kesan dengan cara berbuat. Dengan banyak latihan kesan-kesan yang dterima lebih fungsional. Dengan demikian aktivitas latihan dapat mendukung belajar yang optimal.

Berdasarkan pendapat yang telah dikemukakan, dapat dipahami bahwa ciri-ciri siswa yang aktif dalam pembelajaran adalah yang bertanya, mengeluarkan pendapat, mendengarkan guru menyampaikan materi, mengerjakan tugas, membaca materi pembelajaran dan sebagainya. Dari berbagai bentuk aktivitas belajar, maka guru harus bisa menyediakan aktivitas belajar yang dapat memberikan kesempatan kepada siswa untuk aktif mencari tau penegtahuannya, memberi kesempatan kepada siswa untuk mengembangkan potensipotensi yang ada dalam dirinya.

Jadi, dengan klasifikasi aktivitas seperti yang diuraikan diatas, menunjukkan bahwa aktivitas belajar cukup kompleks dan bervariasi. Jika berbagai macam kegiatan tersebut dapat diciptakan pada saat pembelajaran, maka pembelajaran akan lebih dinamis, tidak membosankan dan benar-benar menjadi pusat aktivitas belajar yang maksimal dan bahkan mempelancar peranannya sebagai pusat dan transformasi kebudayaan. Tetapi sebaliknya ini semua merupakan tantangan yang menuntut jawaban dari pertanyaan guru. Kreativitas guru mutlak diperlukan agar dapat merencanakan kegiatan siswa yang sangat bervariasi itu (Sardiman, 2001: 93).

Selama ini aktivitas yang dominan yang dilakukan siswa terbatas pada mendengarkan, mencatat, dan menjawab pertanyaan, bila guru memberikan pertanyaan. Proses pembelajaran seperti ini kurang mendorong siswa untuk berfikir dan beraktivitas. Untuk lebih meningkatkan pemahaman siswa dalam pembelajaran IPA maka aktivitas siswapun harus lebih ditingkatkan, bukan sekedar mendengar, mencatat, dan menghafal, sehingga dengan peningkatan aktivitas belajar siswa akan tercapai tujuan belajar yaitu perubahan yang diharapkan dalam diri siswa.

Dalam proses pembelajaran, kegiatan mengajar dimulai dengan adanya interaksi anatara guru dan siswa, dalam kegiatan inilah aktivitas siswa akan terlihat. Adanya umpan balik, respon, tanggapn yang diberikan oleh siswa merupakan beentuk-bentuk dari aktivitas belajar siswa seperti mendnegarkan, mengamati, menulis dan lainnya.

Dengan demikian dapat disimpulkan bahwa aktivitas belajar adalah suatu kegiatan yang melibatkan unsur fisik (jasmani) dan fisikis (mental) di dalam proses pembelajaran. 
Aktivitas dalam penelitian ini adalah aktivitas belajar siswa pada mata pelajaran IPA, seperti siswa aktif bertanya, aktif menjawab pertanyaan yang diberikan guru, siswa aktif mengemukakan pendapatnya pada saat pembelajaran.

\section{Metode Kelompok sindikat (Syndicate Group)}

Metode merupakan cara yang dilakukan untuk mencapai tujuan tertentu. Metode terdapat dalam sebuah strategi. Dalam proses pembelajaran, pemilihan metode yang tepat merupakan salah satu hal yang harus dilakukan oleh seorang guru dalam mendesain pembelajaran. Dalam pemilihan metode guru harus melihat kesesuain antara metode dengan materi, tingkat pemehaman siswa, dan lainnya. Akan tetapi sering kita jumpai pemilihan metode terkadang tidak sesuai dengan materi yang disampaikan sehingga proses pembalajaran menjadi tidak terarah. Pemilihan metode yang tepat akan menjadikan proses pembelajaran berjalan dengan efektif. Metode Kelompok ini bisa diterapkan pada kelas yang jumlahnya besar karena dalam proses akan diberikan pembagian tugas dan didiskusikan secara bersama. Hal ini akan memudahkan siswa dalam menyelesaikan dan mencari informasi terkait materi.

Metode dan strategi dalam pembelajaran diibaratkan sebuah layangan, benang pengikat dari layangan diibaratkan strategi dan tulangnya adalah metode, artinya sebuah metode terdapat dalam strategi. Karena metode adalah cara yang digunakan oleh guru dalam melaksanakan sebuah strategi. Untuk melihat posisi metode dalam sebuah pembelajaran, dapat dilihat pada gambar berikut:

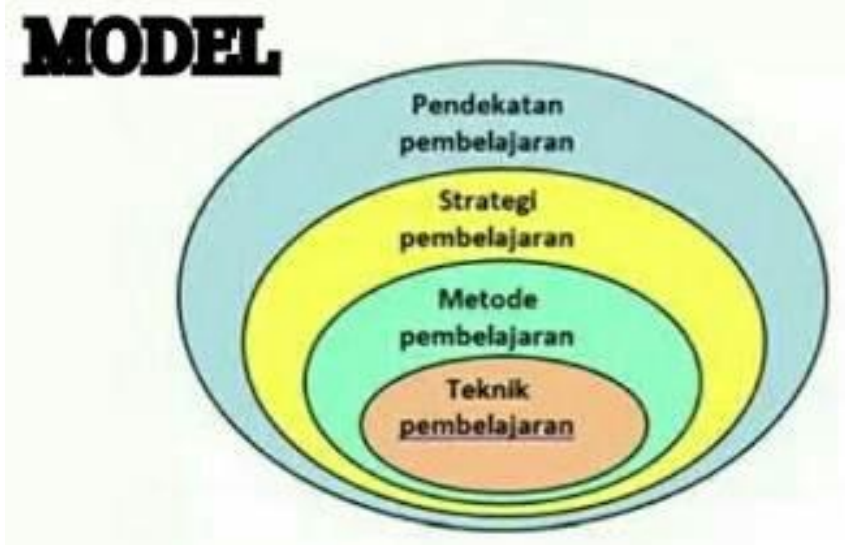

\section{Gambar 1. Hubungan Antara Pendekatan, Strategi, Metode dan Teknik Pembelajaran (Eni Kuswati)}

Syndicate adalah kongsi, gabungan perusahaan, mempersatukan menjadi sindikat. (Jhon M. Echols dan Hassan Shadily, 2005:575). Metode kelompok merupakan metode yang mampu merangsang bisa bekerjasama dengan teman, karena pemberian tugas ini dikerjakan dalam kelompok secara bergotong royong. Metode kelompok sering digunakan oleh guru dalam rangka mencapai tujuan-tujuan seperti memupuk dan memelihara rasa persatuan, solidaritas dengan team, memberi peluang kepada siswa menunagkan hasil pikirannya, menumbuhkan rasa percaya diri untuk mengeluarkan pendapat dan melatih siswa untuk bekerja secara bersama.

Metode kelompok sindikat group (syndicate group) menurut Muchlas Samani dan Hariyanto (2011:155)memiliki berberapa langkah-langkah yaitu: (1) Satu kelompok besar (kelas) dibagi lagi menjadi beberapa kelompok kecil, (2) Masing-masing kelompok kecil mendiskusikan satu tugas tertentu yang berbeda-beda antar kelompok kecil, (3) Guru menjelaskan tema umum tentang masalah, menggambarkan aspek-aspek pokok masalah 
tersebut, (4) Setiap kelompok membahas hanya satu aspek, (5) Guru menyediakan referensi atau sumber-sumber informasi lain, (6) Setiap kelompok sindikat berdiskusi sendiri-sendiri, (7) Pada akhirnya diskusi disampaikan laporan setiap sindikat dan selanjutnya di bawa ke pleno (sidang umum) untuk dibahas lebih lanjut sehingga seluruh aspek dari tema maslah terselesaikan. Langkah-langkah ini sama dengan yang diungkapkan Warsono dan Hariyanto, (2013:82)

Ada beberapa kelebihan metode kelompok sindikat (syndicate group) menurut muchlas Samani dan Hariyanto, (2011:152) yaitu: (1) Untuk membuat sesuatu masalah lebih menarik, (2) Untuk membantu peserta didik terbiasa mengemukakan pendapatnya, (3) Untuk lebih mengenal dan mendalami suatu masalah (4) Untuk menciptakan suasana yang lebih rileks, informal, tetapi tetap terarah dan (5) Untuk menggali pendapat dari peserta didik yang tidak suka bicara, pemalu atau jarang bicara.

Adapun kelemahan dari metode kelompok sindikat (syndicate group) ini : menurut Wina Sanjaya, (2013:156) adalah Sering terjadi pembicaraan dalam diskusi dikuasai oleh 2 atau 3 orang siswa yang memiliki keterampilan berbicara, kadang-kadang pembahasan diskusi meluas, sehingga kesimpulan menjadi kabur, memerlukan waktu yang cukup panjang, yang kadang-kadang tidak sesuai dengan yang direncanakan, dalam diskusi sering terjadi perbedaan pendapat yang bersifat emosional yang tidak terkontrol, akibatnya dapat mengganggu iklim pembelajaran.

\section{Hubungan Antara Metode Kelompok Sindikat (Syndicate Group) dengan Aktivitas Belajar Siswa}

Metode kelompok sindikat (syndicate group) merupakan metode yang bertujuan untuk mengaktifkan siswa, dengan penerapan metode kelompok sindikat (syndicate group) dalam proses pembelajaran siswa akan lebih aktif. Menurut Muchlas Samani dan Hardiyanto, manfaat dari penyelenggaraan diskusi kelompok adalah untuk membantu peserta didik terbiasa mengemukakan pendapatnya, dan untuk menggali pendapat dari peserta didik yang tidak suka bicara, pemalu, atau jarang bicara (Muchlas Samani, 2011:152). Metode ini merangsang siswa untuk mengemukakan pendapat.

Jika dilihat dari kelebihan-kelebihan yang ada pada metode kelompok ini, memberikan manfaat untuk aktivitas siswa. Aktivitas belajar siswa pada aspek visual terlihat pada saat guru memberikan kesempatan bertanya dan mengeluarkan pendapat kepada setiap siswa. Dalam aktivitas belajar aspek emosional juga terlihat, maka dalam proses kerja kelompok atau diskusi ini, siswa akan mampu mengontol emosi, membangun semangat yang tinggi untuk menyelesaikan tugas-tugas.

Berdasarkan penjelasan tersebut, dapat dipahami bahwa metode kelompok sindikat akan menjadikan siswa lebih aktif dalam pembelajaran, tetapi siswa juga terlibat langsung untuk mendapatkan informasi tersebut, dan mendorong siswa mengekspresikan pendapatnya secara bebas. Mengajarkan kepada siswa untuk menghargai pendapat orang lain. Dengan demikian metode kelompok sindikat salah satu alternatif dalam proses pembelajaran untuk meningkatkan aktivitas belajar siswa.

\section{METODE PENELITIAN}

Penelitian ini merupakan penelitian tindakan kelas yang dilakukan dalam dua siklus, dan setiap siklus dilaksanakan dalam dua kali pertemuan. Tahapan-tahapan yang dilalui dalam penelitian tindakan kelas, yaitu: perencanaan tindakan, pelaksanaan tindakan, observasi, dan refleksi. 
Subjek dalam penelitian ini adalah siswa dan guru kelas V tahun pelajaran 2015-2016 dengan jumlah siswa sebanyak 14 orang. Sedangkan objek penelitian ini adalah penerapan metode keompok sindikat (syndicate group) untuk meningkatkan aktivitas belajar siswa kelas V Sekolah Dasar Negeri 009 Teratak Kecamatan Rumbio Jaya Kabupaten Kampar.

Teknik pengumpulan data Observasi dan dokumentasi. Teknik observasi ini digunakan dengan cara mengadakan pengamatan secara langsung di lokasi penelitian untuk mengamati aktivitas guru selama proses pembelajaran dengan metode kelompok sindikat (syndicate group) dan mengamati aktivitas siswa selama proses pembelajaran dengan metode kelompok sindikat. Sedangkan dokumentasi ini digunakan untuk mempelajari profil sekolah, sarana dan prasarana keadaan siswa dan guru serta kurikulum yang digunakan.

Analisis data dilakukan dengan menghitung persentase aktivitas belajar siswa baik aktivitas fisik, mental maupun emosional. Dari data tersebut kemudian ditarik kesimpulan apakah tindakan yang dilaksanakan berhasil atau tidak. Untuk mencari persentase tersebut maka digunakan rumus persentase menurut (Sudijono, 2008: 43) sebagai berikut:

$$
\mathbf{P}=\frac{\mathbf{F}}{\mathbf{N}} \times \mathbf{1 0 0} \%
$$

Keterangan:

$\mathrm{P}=$ Presentase yang dicari

$\mathrm{F}=$ Frekunsi hitung

$\mathrm{N}=$ Frekunsi Harapan

Untuk menentukan rata-rata nilai/skor digunakan rumus menurut (Sudijono 2008:81) sebagai berikut:

\section{HASIL DAN PEMBAHASAN}

$$
\mathbf{M x}=\frac{\Sigma \mathbf{x}}{\mathbf{N}}
$$

Temuan hasil penelitian ini disajikan berdasarkan urutan siklus yang telah dilaksanakan, yaitu siklus I dan siklus II. Pada siklus I pokok bahasan fungsi organ tubuh manusia dan hewan, dengan materi alat pencernaan makanan pada manusia dan alat peredaran darah manusia meliputi dua kali pertemuan. Dan siklus II pokok bahasan tumbuhan hijau dengan materi proses tumbuhan hijau mengolah makanan dan manusia dan hewan bergantung pada makanan terdiri dari dua kali pertemuan. Penelitian dilaksanakan pada hari Senin dan hari Kamis, yang diperlukan untuk setiap kali pertemuan adalah 2 × 35 menit.

\section{Pelaksanaan Tindakan}

\section{a. Siklus I Pertemuan I}

Tindakan penelitian pada pertemuan pertama sikus I dilaksanakan pada hari Senin tanggal 21 September 2015. Jam pertama dan kedua. Materi pelajaran yang dibahas adalah alat pencernaan makanan, dengan standar kompetensi fungsi organ tubuh manusia dan hewan. Kompetensi dasar yang akan dicapai adalah mengidentifikasi alat pencernaan makanan. Sedangkan indikator yang ingin dicapai adalah menjelaskan alat pencernaan makanan, menyebutkan gangguan alat pencernaan makanan, dan menyebutkan cara memelihara alat pencernaan makanan. Kegiatan pembelajaran melalui strategi kelompok sindikat (syndicate group) terdiri dari kegiatan awal, kegiatan inti, dan kegiatan akhir proses pembelajaran.

Kegiatan awal dilaksanakan selama 10 menit yang diawali dengan guru mengucapkan salam dan mengajak siswa berdo'a bersama, kemudian guru mengabsen kehadiran siswa. 
Kemudian guru memberikan motivasi dengan manyuruh siswa mengatakan SIAP. Selanjutnyaguru memberikan apresepsi dengan mengajukan pertanayaan mengenai pelajaran minggu lalu dan menyabutkan materi yang akan dipelajari hari itu. Kemudian guru menyampaikan tujuan pembelajaran yang ingin dicapai, selanjutnya guru menempelkan gambar yang berkaitan dengan materi pada hari itu.

Kegiatan inti dilaksanakan selama 35 menit, diawali dengan siswa mengamati gambar tentang alat pencernaan makanan pada manusia, kemudian siswa memberi pendapat mengenai gambar yang telah disediakan. Selanjutnya guru menjelaskan materi pengantar terkait alat pencernaan makanan pada manusia. kemudian guru membagi siswa kedalam beberapa kelompok dan menjelaskan proses kerja kelompok yang akan dilaksanakan. Kemudian masing-masing kelompok akan membahas dan mendiskusikan satu tugas tertentu yang berbeda dengan kelompok lain. Selanjutnya guru menjelaskan tema umum tentang masalah, mengambarkan aspek-aspek pokok masalah tersebut. Kemudian guru menyediakan referensi atau menyediakan sumber-sumber informasi lain, selanjutnya setiap kelompok berdiskusi sendiri-sendiri. Kemudian guru memerintahkan kembali bahwa setiap kelompok mebahas satu masalah. Kemudian siswa menampaikan laporan dari setiap kelompok sindikat dan selanjutnya dibawa ke sidang pleno (sidang umum) untuk dibahas lebih lanjut. Kemudian diberikan kesempatan kepada siswa lain untuk menyanggah dan membrikan komentar dan selanutnya guru memberikan kesempatan bertanya kepada siawa yang belum paham.

Pada kegiatan akhir guru bersama dengan siswa menyimpulkan hasil pembelajaran pada hari itu. Kemudiaan memberikan tugas untuk dikerjakan dirumah dengan tujun untuk mengevaluasi hasil pembelajaran hari itu. Guru mengakhiri pembelajaran dengan mengcapkan salam.

\section{b. Siklus I Pertemuan II}

Tindakan penelitian pada pertemuan pertama sikus I dilaksanakan pada hari Kamis tanggal 24 September 2015. Jam ketiga dan keempat. Materi pelajaran yang dibahas adalah alat peredaran darah pada manusia, dengan standar kompetensi fungsi organ tubuh manusia dan hewan. Kompetensi dasar yang akan dicapai adalah menentukan alat peredaran darah pada manusia. Sedangkan indikator yang ingin dicapai adalah menjelaskan alat peredaran darah pada manusia, menyebutkan gangguan alat peredaran darah, dan menyebutkan cara memelihara alat peredaran darah. Kegiatan pembelajaran melalui strategi kelompok sindikat (syndicate group) terdiri dari kegiatan awal, kegiatan inti, dan kegiatan akhir proses pembelajaran.

Kegiatan awal dilaksanakan selama 10 menit yang diawali dengan guru mengucapkan salam dan mengajak siswa berdo'a bersama, kemudian guru mengabsen kehadiran siswa. Kemudian guru memberikan motivasi dengan manyuruh siswa mengatakan SIAP. Selanjutnyaguru memberikan apresepsi dengan mengajukan pertanayaan mengenai pelajaran minggu lalu dan menyabutkan materi yang akan dipelajari hari itu. Kemudian guru menyampaikan tujuan pembelajaran yang ingin dicapai, selanjutnya guru menempelkan gambar yang akan dipelajari.

Kegiatan inti dilaksanakan selama 35 menit, diawali dengan siswa mengamati gambar alat peredaran darah pada manusia, kemudian siswa memberi pendapat mengenai gambar yang telah disediakan. Selanjutna guru menjelaskan materi pengantar terkait macam-macam makanan bergizi. kemudian guru membagi siswa kedalam beberapa kelompok dan menjelaskan proses kerja kelompok yang akan dilaksanakan. Kemudian masing-masing kelompok akan membahas dan mendiskusikan satu tugas tertentu yang berbeda dengan kelompok lain. Selanjutnya guru menjelaskan tema umum tentang masalah, mengambarkan aspek-aspek pokok masalah tersebut. Kemudian guru menyediakan referensi atau 
menyediakan sumber-sumber informasi lain, selanjutnya setiap kelompok berdiskusi sendirisendiri. Kemudian guru memrintahkan kembali bahwa setiap kelompok memsbahas satu masalah. Kemudian siswa menampaikan laporan dari setiap kelompok sindikat dan selanjutnya dibawa ke sidang pleno (sidang umum) untuk dibahas lebih lanjut. Kemudian diberikan kesempatan kepada siswa lain untuk menyanggah dan membrikan komentar dan selanutnya guru memberikan kesempatan bertanya kepada siawa yang belum paham.

Pada kegiatan akhir guru bersama dengan siswa menyimpulkan hasil pembelajaran pada hari itu. Kemudiaan memberikan tugas untuk dikerjakan dirumah dengan tujun untuk mengevaluasi hasil pembelajaran hari itu. Guru mengakhiri pembelajaran dengan mengcapkan salam.

Refleksi siklus I aktivitas belajar siswa pada mata pelajaran Ilmu Pengetahuan Alam pada pertemuan 1 dan 2 berada pada klasifikasi "kurang" karena 58,42\% berada pada rentang 50\%-59\%. Aktivitas belajar siswa pada mata pelajaran Ilmu Pengetahuan Alam belum mencapai standar keberhasilan yang ditetapkanm, yaitu 75\%. Maka berdasarkan hasil pembahasan peneliti dan pengamat diketahui penyebab aktivitas belajar siswa pada siklus I belum mencapai indikator keberhasilan yang telah ditetapkan. Maka penelitian dilanjutkan pada siklus II. Dalam pembelajaran siklus II diharapkan dapat meningkat aktivitas belajar siswa dengan memperbaiki kekurangan-kekurangan yang ada pada siklus I.

Setelah dilaksanakan tindakan melalui strategi kelompok sindikat (syndicate group) dan diamati oleh bserver, selanjutnya peneliti melakukan refleksi yang tujuannya untuk memperbaiki kesalahan dan kelemahan yang terjadi pada siklus I. adapun kelemahan yang perlu diperbaiki yaitu,guru menggunakan gambar yang kurang jelas, sehingga siswa sulit mengamatai, guru kurang jelas dalam pemberian instruksi, yang lebih utama tata bahasa dan fokal, guru kurang tegas dan lemah dalam memberi semnagat kepada siswa untuk menugaskan siswa dalam melakukan diskusi kelompok agar semua siswa melakukan dengan baik dan benar. Guru tidak mengalokasikan waktu dengan baik.

\section{c. Siklus II Pertemuan I}

Tindakan penelitian pada pertemuan ketiga sikus II dilaksanakan pada hari Senin tanggal 28 September 2015. Jam pertama dan kedua. Materi pelajaran yang dibahas adalah Pembuatan makanan pada tumbuhan hijau, dengan standar kompetensitumbuhan hijau. Kompetensi dasar yang akan dicapai adalah pembuatan makanan pada tumbuhan hijau. Sedangkan indikator yang ingin dicapai adalah menjelaskan pengertian tumbuhan hijau, menjelaskan proses tumbuhan hijau membuat makanan, menebutkan tempat menyimpan timbunan makanan pada tumbuhan . Kegiatan pembelajaran melalui strategi kelompok sindikat (syndicate group) terdiri dari kegiatan awal, kegiatan inti, dan kegiatan akhir proses pembelajaran.

Kegiatan awal dilaksanakan selama 10 menit yang diawali dengan guru mengucapkan salam dan mengajak siswa berdo'a bersama, kemudian guru mengabsen kehadiran siswa. Kemudian guru memberikan motivasi dengan manyuruh siswa mengatakan SIAP. Selanjutnya guru memberikan apresepsi dengan mengajukan pertanayaan mengenai pelajaran minggu lalu dan menyabutkan materi yang akan dipelajari hari itu. Kemudian guru menyampaikan tujuan pembelajaran yang ingin dicapai, selanjutnya guru menempelkan gambar yang berkaitan dengan materi pada hari itu.

Kegiatan inti dilaksanakan selama 35 menit, diawali dengan siswa mengamati gambar yang tentang proses tumbuhan hijau dalam mengolah makanan, kemudian siswa memberi pendapat mengenai gambar yang telah disediakan. Selanjutna guru menjelaskan materi pengantar terkait alat peredaran darah pada manusia. kemudian guru membagi siswa kedalam beberapa kelompok dan menjelaskan proses kerja kelompok yang akan dilaksanakan. Kemudian masing-masing kelompok akan membahas dan mendiskusikan 
satu tugas tertentu yang berbeda dengan kelompok lain. Selanjutnya guru menjelaskan tema umum tentang masalah, mengambarkan aspek-aspek pokok masalah tersebut. Kemudian guru menyediakan referensi atau menyediakan sumber-sumber informasi lain, selanjutnya setiap kelompok berdiskusi sendiri-sendiri. Kemudian guru memrintahkan kembali bahwa setiap kelompok mebahas satu masalah. Kemudian siswa menampaikan laporan dari setiap kelompok sindikat dan selanjutnya dibawa ke sidang pleno (sidang umum) untuk dibahas lebih lanjut. Kemudian diberikan kesempatan kepada siswa lain untuk menyanggah dan membrikan komentar dan selanutnya guru memberikan kesempatan bertanya kepada siawa yang belum paham.

Pada kegiatan akhir guru bersama dengan siswa menyimpulkan hasil pembelajaran pada hari itu. Kemudiaan memberikan tugas untuk dikerjakan dirumah dengan tujun untuk mengevaluasi hasil pembelajaran hari itu. Guru mengakhiri pembelajaran dengan mengcapkan salam.

\section{d. Siklus II Pertemuan II}

Tindakan penelitian pada pertemuan pertama sikus I dilaksanakan pada hari Kamis tanggal 1 Oktober 2015. Jam Ketiga dan keempat. Materi pelajaran yang dibahas adalah manusia dan hewan bergantung pada makanan,standar kompetensitumbuhan hijau. Kompetensi dasar yang akan dicapai adalah mengidentifikasi manfaat makanan pada manusia dan hewan. Sedangkan indikator yang ingin dicapai adalah menjelaskan pentingnya makanan bagi manusia dan hewan,. Kegiatan pembelajaran melalui strategi kelompok sindikat (syndicate group) terdiri dari kegiatan awal, kegiatan inti, dan kegiatan akhir proses pembelajaran.

Kegiatan awal dilaksanakan selama 10 menit yang diawali dengan guru mengucapkan salam dan mengajak siswa berdo'a bersama, kemudian guru mengabsen kehadiran siswa. Kemudian guru memberikan motivasi dengan manyuruh siswa mengatakan SIAP. Selanjutnya guru memberikan apresepsi dengan mengajukan pertanayaan mengenai pelajaran minggu lalu dan menyabutkan materi yang akan dipelajari hari itu. Kemudian guru menyampaikan tujuan pembelajaran yang ingin dicapai, selanjutnya guru menempelkan gambar yang berkaitan dengan materi pada hari itu.

Kegiatan inti dilaksanakan selama 35 menit, diawali dengan siswa mengamati gambar tentang rantai makanan, kemudian siswa memberi pendapat mengenai gambar yang telah disediakan. Selanjutna guru menjelaskan materi pengantar terkait tumbuhan hijau. kemudian guru membagi siswa kedalam beberapa kelompok dan menjelaskan proses kerja kelompok yang akan dilaksanakan. Kemudian masing-masing kelompok akan membahas dan mendiskusikan satu tugas tertentu yang berbeda dengan kelompok lain. Selanjutnya guru menjelaskan tema umum tentang masalah, mengambarkan aspek-aspek pokok masalah tersebut. Kemudian guru menyediakan referensi atau menyediakan sumber-sumber informasi lain, selanjutnya setiap kelompok berdiskusi sendiri-sendiri. Kemudian guru memrintahkan kembali bahwa setiap kelompok memsbahas satu masalah. Kemudian siswa menampaikan laporan dari setiap kelompok sindikat dan selanjutnya dibawa ke sidang pleno (sidang umum) untuk dibahas lebih lanjut. Kemudian diberikan kesempatan kepada siswa lain untuk menyanggah dan membrikan komentar dan selanutnya guru memberikan kesempatan bertanya kepada siawa yang belum paham.

Pada kegiatan akhir guru bersama dengan siswa menyimpulkan hasil pembelajaran pada hari itu. Kemudiaan memberikan tugas untuk dikerjakan dirumah dengan tujun untuk mengevaluasi hasil pembelajaran hari itu. Guru mengakhiri pembelajaran dengan mengcapkan salam.

Refleksi siklus II aktivitas belajar siswa pada mata pelajaran Ilmu Pengetahuan Alam pada pertemuan I dan II, aktivitas belajar siswa berada pada klasifikasi "baik" karena 
presentase $77,81 \%$ berada pada rentang 70\%-79\%. Terjadi peningkatan yang signifikan terhadap ketuntasan secara klasikal dan individual disebabkan karena siswa telah memahami proses. Hal ini juag disebabkan oleh guru selalu memotivasi siswa untuk belajar dengan semangat. Aktvitas guru dan siswa meningkat sehingga proses pembelajaran menjadi semakin baik. Oleh karena itu peneliti tidak melakukan perencanaan untuk siklus selanjutnya, karena pada penelitian ini dilakukan sebanyak dua siklus.

\section{Analisis Hasil Penelitian}

\section{a. Aktivitas Guru}

Hasil observasi aktivitas guru selama proses pembelajaran yang dilakukan dapat dilihat pada tabel berikut:

\section{Tabel 1. Hasil Aktivitas Guru Selama Proses Pembelajaran IPA} di Kelas V SDN 009 Teratak

\begin{tabular}{ccccc}
\hline Siklus & Pertemuan & Jumlah & Presentase & Kategori \\
\hline \multirow{2}{*}{ I } & Pertemuan 1 & 17 & $60,71 \%$ & Cukup \\
& Pertemaun 2 & 18 & $64,42 \%$ & Cukup \\
II & Pertemuan 1 & 22 & $78,58 \%$ & Baik \\
& Pertemuan 2 & 25 & $89,26 \%$ & Sangat Baik \\
\hline
\end{tabular}

Berdasarkan tabel 1. dapat dilihat pertemuan pertama aktivitas guru memperoleh skor 17 dengan rata-rata presentase $60,71 \%$ (kategori cukup), sedangkan pada pertemuan kedua memperoleh skor 18 dengan rata-rata 64,42\% (kategori cukup), pada siklus I pertemuan pertama dan kedua menaglami kenaikan,namun masih berada pada kategori cukup. Pada siklus II pertemuan pertama aktivitas guru mengalami skor 22 dengan presentase 78,58\% (kategori baik), dan pertemuan kedua memperoleh skor 25 dengan presentase 89,26\% (kategori sangat baik). Pada siklus II aktivitas guru sudah mengalami peningkatan dari siklus I, hal ini dikarenakan guru sudah menguasai proses pembelajaran dengan baik.

\section{b. Aktivitas Siswa}

Hasil observasi aktivitas siswa selama proses pembelajaran dapat dilihat pada tabel berikut:

\section{Tabel 2. Hasil Aktivitas Siswa Selama Proses Pembelajaran IPA di Kelas V SDN 009 Teratak}

\begin{tabular}{ccccc}
\hline Siklus & Pertemuan & Jumlah & Presentase & Kategori \\
\hline I & Pertemuan 1 & 58 & $59,18 \%$ & Kurang \\
& Pertemaun 2 & 62 & $63,27 \%$ & Cukup \\
II & Pertemuan 1 & 69 & $70,41 \%$ & Baik \\
& Pertemuan 2 & 89 & $90,82 \%$ & Sangat baik \\
\hline
\end{tabular}

Berdasarkan hasil tabel 2 terlihat bahwa rata-rata aktivitas siswa pada pertemuan pertama adalah 59,18\% (kategori kurang) dan pada pertemuan kedua adalah 63,27\% (kategori cukup), sehingga terlihat adanya peningkatan pada siklus I dari pertemuan pertama dan pertemuan kedua. Pada siklus II ada terlihat peningkatan aktivitas siswa pada pertemuan pertama 70,41\% (kategori baik) dan pada pertemuan kedua 90,82\% (kategori sangat baik).

Meningkatnya aktivitas siswa tersebut sangat erat kaitannya dengan motivasi guru dan aktivitas guru dalam proses pembelajaran, karena aktivitas siswa merupakan respon dari kegiatan guru. Jika aktivitas guru terlaksana dengan baik dan efektif, maka akan memberi pengaruh kepada aktivitas siswa. Sebagai salah satu contoh aktivitas guru dalam menyampaikan instruksi, apabila penyampaiannya jelas dan terarah makan respon yang diberikan oleh siswa juga akan baik. Dan Sebaliknya, apabila aktivitas guru tidak terlaksana 
dengan efektif maka aktivitas siswa tidak terlaksana dengan baik. Pada aktivitas siswa ini terlihat adanya peningkatan pada setiap pertemuan. Peningkatan ini terjadi karena timbul semangat dari setiap siswa untuk mengikuti pembelajaran, serta siswa sudah mulai memahami langkah-langkah dalam pembelajaran. Peningkatan ini tidak terlepas dari aktivitas yang diberikan guru. Karena aktivitas siswa merupakan respon atau umpan balik dari ang diberikan guru.

\section{c. Aktivitas Belajar Siswa}

Hasil observasi aktivitas belajar sisiwa selama proses pembelajaran dengan menggunakan metode kelompok sindikat dapat dilihat pada tabel berikutberikut:

\section{Tabel 3. Hasil Aktivitas Belajar Siswa Selama Proses Pembelajaran IPA di Kelas V SDN 009 Teratak}

\begin{tabular}{lccc}
\hline \multicolumn{1}{c}{ Aktivitas Belajar Siswa } & Sebelum Tindakan & Siklus I & Siklus II \\
\hline Visual activities & $42,86 \%$ & $58,93 \%$ & $80,36 \%$ \\
Oral activities & $37,5 \%$ & $57,14 \%$ & $80,36 \%$ \\
Writing activities & $42,86 \%$ & $57,14 \%$ & $75 \%$ \\
Emotional activities & $35,72 \%$ & $60,72 \%$ & $78,75 \%$ \\
\hline Jumlah & $\mathbf{4 1 , 0 7 \%}$ & $\mathbf{5 8 , 4 2 \%}$ & $\mathbf{7 7 , 8 1 \%}$ \\
\hline Kategori & Gagal & Kurang & Baik \\
\hline
\end{tabular}

Dari tabel 3 diatas, aktivitas belajar siswa pada sebelum tindakan yaitu 41,07\% dengan kategori "gagal" karena berada pada berada pada rentang 0-49\%. kemudian setelah diterapkan strategi kelompok sindikat (syndicate group) pada siklus I, aktivitas belajar siswa meningkat menjadi 58,42\% dengan kategori "kurang" dan masih jauh dari indikator yang telah ditetapkan yaitu 75\%. Sedangkan pada siklus II, aktivitas belajar siswa meningkat menjadi 77,81\% dengan kategori "Baik", artinya sudah mencapai indikator yang telah ditetapkan.

\section{Aktivitas Guru}

Pembahasan hasil penelitian berdasarkan pada hasil analisis penelitian tentang aktivitas guru selama proses pembelajaran berlangsung sesuai dengan data yang penelitian yang ditemukan. Ada beberapa kelemahan yang pada siklus I pertemuan pertama guru masih kurang dalam menguasi kelas, pada siklus II aktivitas guru mengalamai peningatan.

Pada pertemuan pertama aktivitas guru secara umum sudah dikategorikan cukup baik, tetapi observer menyarankan agar guru lebih memperhatikan pengalokasian waktu dan memperhatikan siswa yang bermain dan ribut selama proses pembelajaran berlangsung. Siswa juga bingung dalam melakukan proses diskusi. Guru disarankan untuk menggunakan bahasa yang singkat tepat serta suara yang jelas. Gambar yang digunakan guru juga harus diperjelas. Suara dan Instruksi yang jelas akan memudahkan siswa dalam mendengarkan arahan dari guru, sehingga siswa tidak bingung untuk melakukan langkah-langkah pembelajaran.

Pertemuan kedua aktivitas yang dilakukan guru sudah mengalami peningkatan namun masih berada pada kategori cukup. Saran dari observer agar guru bisa memotivasi siswa untuk aktif dalam diskusi seperti memberikan pertanyaan dan memberikan tanggapan. Guru disarankan untuk bersemangat dalam memberikan memberikan motivasi tersebut, karena apabila guru bersemangat tentunya akan memberi pengaruh kepada siswa.

Pada pertemuan ketiga sudah sangat baik, sesuai dengan RPP, saran dari observer guru lebih memperhatikan siswa yang pemalu dan tidak mau bertanya. Sehingga guru tidak terfokus kepada siswa yang aktif saja. Saran dari observer agar guru tidak terfokus kepada siswa yang aktif, guru juga memberi perhatian lebih kepada siswa yang pemalau dan takut untuk memberikan argumen. Dengan demikian 
Pertemuaan keempat, aktivitas yang dilakukan guru sudah berjalan dengan sangat baik, sesuai dengan yang direncanakan. Aktivitas siswa juga berjalan dengan sangat baik. Siswa yang pemalu dalam berbicara sudah berani mengeluarkan pendapatnya. Guru sudah mengeluarkan suara dengan jelas dan menggunakan bahasa yang tegas. Guru juga tidak hanya memberikan materi tetapi dengan semangat juga memberikan motivasi kepada siswa. Dan guru juga tidak terfokus kepada sisiwa yang aktif saja.

Dari pengamatan yang dilakukan dapat disimpulkan bahwa penerapan metode kelompok sindikat (syndicate group) dapat meningkatkan aktivitas belajar siswa pada mata pelajaran IPA di kelas V SD Negeri 009 Teratak. Dari keseluruhan aktivitas guru selama proses pembelajaran dapat meningkatkan aktivita belajar siswa.

\section{Aktivitas Siswa}

Aktivitas siswa sangat erat kaitannya dengan motivasi dan akktivitas guru berikan. Pada aktivitas adalah umpan balik atau respon yang diberikan oleh siswa dari kegiatankegiatan yang dilakukan oleh guru. Pada siklus I pertemuan pertama aktivitas siswa tergolong kedalan kategori kurang, dalam arti kata aktivitas siswa sangat jauh dari harapan. Hal ini disebabkan oleh berberapa hal, untuk pertama kali penerapan metode kelompok sindikat siswa masih canggung dan belum paham dengan instruksi yang diberikan guru. Siswa juga mengalami kesulitan dalam memahami dan mengamati gambar yang diberikan oleh guru karena terlalu kecil dan jarak meja siswa ke papan tulis tergolong jauh. Siswa juga mengalamai kesulitan dalam aspek mendengarkan dikarenakan guru kurang jelas dalam memberikan intruksi. Siswa tidak tepat waktu dalam mengerjakan hasil kerja dan pembahasan dalam kelompok dikarenakan guru tidak mengalokasikan waktu dengan baik.

Pada pertemuan kedua aktivitas siswa mengalami peningkatan, karena guru telah melakukan perbaikan. Siswa sudah mulai paham dengan tujuan metode kelompok sindikat, gambar yang dipaparkan oleh guru juga sudah bisa diamati oleh siswa. Namun pada perteman kedua ini masih terdapat beberapa kelemahan diantaranya guru masih belum jelas dalam menyampaikan instruksi, siswa masih belum tepat waktu dalam menyelesaikan tugass dan pembahasan dalam kelompok.

Pada Siklus II, terjadi peningkatan yang signifikan dalam aktivitas siswa. Pada pertemuan ketiga kategori aktivitas siswa berada dalam kategori baik,pada pertemuan sebelumnya masih berada dalam kategoti cukup. Dan pada pertemuan keempat aktivitas siswa berada dalam kategori sangat baik dengan presentase 90,82\%. Dapat diartikan aktivitas siswa dalam pelaksanaan metode ini berjalan dengan baik dan sempurna. Hal dikarenakan dalam proses pembelajaran siswa telah memahami dan mengerti dengan penerapan metode ini, hal ini juga disebabkan karena guru selalu memotivasi siswa belajar dengan baik. Aktivitas siswa meningkat sehingga proses pembelajaran menjadi semakin menarik.

\section{Aktivitas Belajar Siswa}

Dari data tentang aktivitas belajar siswa selama proses pembelajaran berlangsung sesuai dengan data penelitian. Hanya saja kelemahan terdapat pada siklus I, siswa masih kurang dalam keterlibatan proses pembelajaran. Siswa masih ada yang bermain-main pada saat kerja kelompok, siswa mengalami kesulitan dalam mengamati gambar, sering kali diskusi dikuasai oleh orang yang aktif saja dan dalam mendengarkan siswa juga mengalamai kesulitan karena intruksi yang diberikan oleh guru kurang jelas pada siklus I pertemua pertama dan kedua. Pada siklus II setiap aspek aktivitas belajar siswa mengalamai peningkatan, sehingga setiap aspek aktivitas belajar siswa yang diamati menunjukkan adanya perubahan ke yang lebih baik pada saat proses pembelajaran berlangsung, baik visual activities, oral activities, listening activities, writing activities, mental activities, emotional activities.

Dengan adanya metode kelompok sindikat (syndicate group)dapat memberikan ransangan terhadap siswa dalam terlibat aktif pada proses pembelajaran. Karena pada 
dasarnya metode ini memiliki kelebihan dalam mengaktifkan siswa pada proses pembelajaran. Pada pertemuan pertama siswa masih terlihat kurang bersemangat dan tidak aktif dalam kegiatan pembelajaran, setelah pertemuan kedua mulai adanya umpan balik yang diberikan oleh siswa terhadap kegiatan-kegiatan yang diberikan oleh guru, sehingga setiap aspek aktivitas belajar siswa mulai terlihat dan menunjukkan adanya peningkatan.

Analisis data tentang ketercapaian aktivitas belajar siswa secara klasikal dan individual diperoleh fakta-fakta bahwa terjadi peningkatan jumlah siswa yang mengalami peningkatan dalam aktivitas belajarnya berdasarkan data awal, siklus I (pertemuan pertama dan kedua), siklus II (pertemuan ketiga dan keempat). Presentase data awal aktivitas belajar siswa sebelum diterapkan metode kelompok sindikat (syndicate group) dan sesudah penerapan metode kelompok sindikat (syndicate group) yaitu dapat dilihat pada gambar 1 .

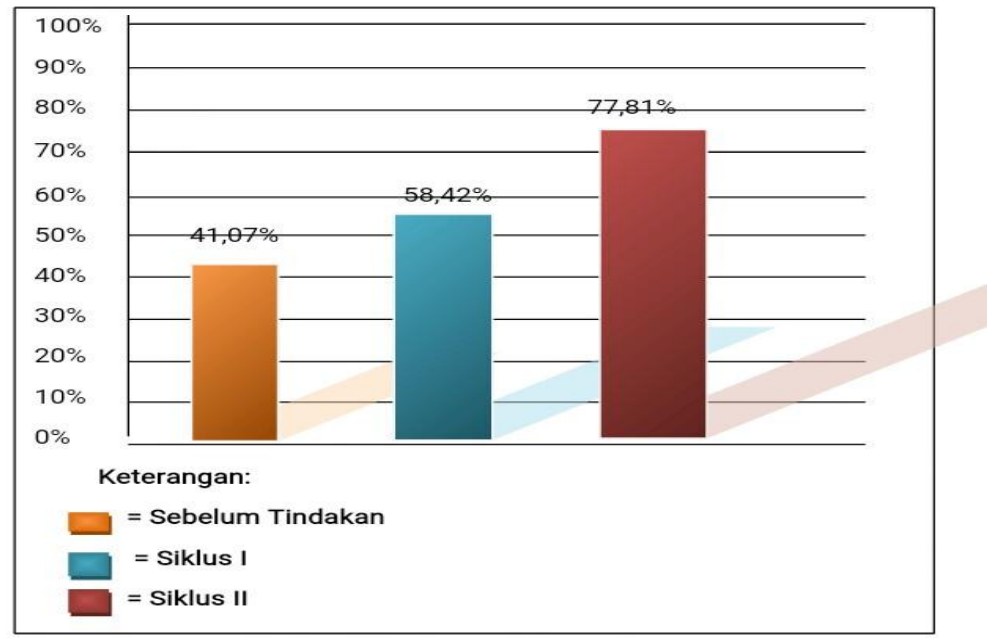

\section{Gambar 2. Grafik Aktivitas Belajar Siswa pada Penerapan Metode kelompok Siklus I dan Siklus II}

Dari hasil pengamatan, siswa lebih bersemangat dan termotivasi dengan penerapan pembelajaran baru yang mereka alami, yaitu penerapan metode kelompok sindikat (syndicate group). Dengan penerapan metode kelompok sindikt (syndicate group) diharapakan siswa aktif dan terlibat dalam setiap aspek aktivitas belajar. Karena ketercapaian tujuan pembelajaran yang efektif juga dilihat dari aktivitas belajar siswa. Dengan tercapainya aktivitas belajar siswa ini tentu akan berdampak kepada pemahaman siswa yang nantinya akan memberi pengaruh kepada hasil belajar siswa.

Metode kelompok sindikat (syndicate gorup) terdapat beberapa aktivitas seperti aktivitas visual, aktivitas visual ini akan meningkat melalui memperhatikan guru menyampaikan materi pelajaran, memahami penjelasan dan instruksi dari guru. Kemudian aktivitas berpikir, dengan berpikir ini siswa juga akan meningkat karena siswa mengembangkan kemampuan berpikirnya untuk mengidetifikasi, dan menuliskan konsep materi terkait gambar atau bahan bacaan. Setelah melalui proses berfikir siswa akan dihadapkan pada kegiatan-kegiatan lisan (oral) yaitu kegiatan untuk mengemukakan pendapatnya sebagai hasil pemikirannya. Dengan demikian selama pembelajaran berlangsung siswa akan aktif dan pembelajaran berjalan seperti yang diharapkan. Teori ini sesuai dengan yang telah peneliti lakukan selama penelitian. Dalam pelaksanaan dilapangan.

Penggunaan penerapan metode kelompok sindikat (syndicate group) di kelas V SD Negei 009 Teratak terdapat beberapa kebaikan dan kelemahan yang peneliti temukan. Adapun kelebihan-kelebihan tersebut yaitu, membuat sesuatu masalah lebih menarik, membantu peserta didik terbiasa mengemukakan pendapatnya, siswa lebih mengenal dan mendalami suatu masalah, menciptakan suasana yang lebih rileks, informal tetapi tetap terarah dan 
menggali pendapat dari peserta didik yang tidak suka bicara, pemalu atau jarang bicara.Sedangkan kekurangan-kekurangannya yaitu, sering terjadi pembicaraan dalam diskusi dikuasai oleh 2 atau 3 orang siswa yang memiliki keterampilan berbicara, kadang-kadang pembahasan diskusi meluas, sehingga kesimpulan menjadi kabur, memerlukan waktu yang cukup panjang, yang kadang-kadang tidak sesuai dengan yang direncanakan, dalam diskusi sering terjadi perbedaan pendapat yang bersifat emosional yang tidak terkontrol, akibatnya dapat mengganggu iklim pembelajaran.

Dalam beberapa hal penelitian pendidikan mempunyai keterbatasan yang perlu disadar oleh peneliti. Beberapa masalah tersebut merupakan konsekunsi dari kompleksitas masalah, dan metodologi yang bersumber kepada subjek penelitian pendidikan itu sendiri, yakni manusia. Kompleksitas masalah pendidikan merupakan pembatas karena fenomena yang muncul dalam penelitian pendidikan merupakan damapak interaksi dan stimulasi dari guru dan siswa. Interasi inilah yang tidak dapat diprediksi. Peneliti perlu menyadari bahwa tidak hanya berhubungan pada elemen manusia saja tetapi dengan berbagai elemen stimusional yang begitu banyak. Keterbatasan keduanya dalam penelitian pendidikan adalah metodologi yang digunakan. Fenomena-fenomena yang dikaji berhubungan dengan mencari solusi, perbaikan serta mengukur karakteristik peserta didik.

\section{SIMPULAN}

Hasil penelitian menunjukkan siswa dalam kegiatan pembelajaran sebelum penerapan metode adalah 41,07\% dengan kategori gagal. Setelah menerapkan metode kelompok sindikat pada siklus I, aktivitas belajar siswa meningkat menjadi 58,42\% dengan kategori kurang. Pada siklus II, meningkatkan aktivitas belajar siswa menjadi 77,81\%. Dapat disimpulkan bahwa, melalui metode kelompok sindikat kegiatan belajar siswa dapat meningkat.

\section{REFERENSI}

Dimyati dan Mudjiono. (2012). Belajar dan Pembelajaran. Jakarta: PT Rineka Cipta.

Hasbullah. (2011). Dasar-dasar Imu Pendidikan. Jakarta: PT Raja Gravindo Persada.

Jhon M. Echols dan Hassan Shadily. (2005). Kamis Inggris Indonesia. Jakarta: PT Gramedia Jakarta.

Muchlas Samani dan Hariyanto. (2011). Pendidikan Karakter. Bandung: PT Remaja Rosadakarya.

Nana Sudjana. (2011). Dasar-Dasar Proses Belajar Mengajar. Bandung: Sinar Baru Algensindo.

Oemar Hamalik. (2006). Proses Belajar Mengajar. Jakarta: Bumi Aksara.

Sardiman. (2001). Interaksi dan Motivasi Belajar Mengajar. Jakarta: Raja Grafindo Persada.

Sudjiono, Anas. (2008). Pengantar Statistik Pendidikan. Jakarta: Rasa Grafindo Persada.

Susilawati. (2013).Pembelajaran IPA di Madrasah Ibtidaiyah, Pekanbaru: Benteng Media CV.

Syaiful Bahri Djamarah. (2011). Psikologi Belajar, Jakarta: PT Rineka Cipta. 
Warsono dan Hariyanto. (2013). Pembelajaran Aktif Teori dan Asesmen, Bandung.

Wina Sanjaya. (2013). Strategi Pembelajaran Berorientasi Standa Proses Pendidikan, Jakarta: Kencana. 